author(s) Vasco Branco vasco.branco@ua.pt

Francisco Providência correio@fprovidencia.com

Helena Barbosa helenab@ua.pt

Nuno Dias ndias@ua.pt

Joana Quental joana.quental@ua.pt

Álvaro Sousa alvarosousa@ua.pt

Gonçalo Gomes goncalo@ua.pt

ID+ / University of Aveiro

Fátima Pombofpombo@ua.pt

ID + / University of Leuven

Alice Semedo semedo.alice@gmail.com

Sandra Senra sandra.msenra@gmail.com

CITCEM / Faculty of Arts, University of Porto

Rui Mendonça gemeorui@gmail.com

ID+ / Faculty of Fine Arts, University of Porto

\title{
Developing an Interpretation Centre for Portuguese Design - CIDESP.PT
}

Considering the lack of importance of the discipline in the Portuguese and international context, this paper aims to present and discuss a museological and museographic project that's in its early stage and started to be developed concerned with Portuguese design history and design studies. The focus on the theme Portuguese design is justified by the extent of the heritage of communication artefacts, equipment and environment, presently dispersed about the country and at risk of disappearing into oblivion.

The paper present's an approach based in a new hermeneutical dimension which methodology will be centered on the study of the artefacts based on the 'inverse design' and it will be focused on the morphogenetic study, related with their importance next to the public sphere. Considering the specificity of Portuguese design history the paper refers' some notes on this subject, giving some examples that can be considered as some starting references to proceed with the project. The results of this research it will be declined in augmented interactive representations regarding the importance of the personal narratives related with the selected artifacts. This project seeks to contribute to the minimization of the invisibility of design Portuguese knowledge and to be used as a model to other countries.

keywords portuguese design history, inverse design, museography and museology of design

\section{Introduction}

The apparent lack of public interest about Portuguese design, the incorrect use of the concept and the scanty attention paid to its culture on the part of industry and of the State, has devastating consequences for the international affirmation of its identity and obvious obstacles to its future and national development. In order to promote the Portuguese design the CIDES.PT aims to research, develop and evaluate new approaches to history in museologically terms. 
For the effective evaluation of Portuguese material culture, the operative vision of design is required allowing the uniqueness of that culture to be fully recognized, both in Portugal and abroad. In spite some published studies about Portuguese design (Manaças, 2005), (Souto, 2009), (Barbosa, 2011), (Fragoso, 2012), the theme is still largely dispersed and unsystematized. To give visibility to the Portuguese design, the project will foster the construction of interactive narratives that can complement and transcend the construction of the physical collections, while simultaneously providing a space for shared critical debate.

\section{The CIDES.PT project}

This project aims to transform the concepts and studies we have been developing into methodologies and prototypes that can be evaluated enabling our team' to go further within this research field. Taking advantage of our design research experience (Barbosa [et. al.], 2011) we will add a new hermeneutic dimension to the historical, anthropological and ethnographic perspectives traditionally used in the research about material culture. This new dimension is centred on the study of the morphogenesis, motivation and opportunity of artefacts, devices and services designed by Portuguese designers. It involves highlighting the semantic and abductive dimension of the artefacts by, on the one hand, uncovering the series of decisions, which led to this particular solution, and on the other, demonstrating the proliferation of meanings that the market promotes and its use provokes. We believe that an "inverse design" (a term that has been coined through analogy with "inverse engineering"), involving retracing the creative process from the object itself to the idea that gave rise to it, will enable us to identify Portuguese identity characteristics for these artefacts, which will do justice to its long history and the wealth of geographic and cultural influences that have contributed to it. Museologically, another innovative aspect has to do with the use of information technology to capture and reveal these artefacts, using a dynamic and multifaceted form of representation that is open to new forms of interaction (i.e. multi-touch devices, augmented reality). This will encourage public intervention, promoting the participation of people in the reconstitution of the meanings attached to the experiential dimension of these artefacts (Giaccardi, 2006). The use of narratives of designers / producers, collectors and users / visitors also represents a partial change analysis over previous approaches as it emphasizes the processes and the indeterminacy of meaning. The narrative approach opens the way to further explore the types of stories that people tell through and about objects. This understanding about collections and artefacts' research found in new theoretical studies of museums and material culture indicates (Dudley, 2009; Tilley et al 2006), in a way, a dematerialization of objects as mere semiotic indicators or their re-materialization in social, political and economic contexts. As Peter Vergo (1989) had already announced, objects are reticent; one assumes someone speaks for them. They are reluctant or a deliberate paradox; they are discursive objects or rhetorical objects, that is, they are subject to constantly changing semantic fields (Taborsky, 1990; Hein, 2000; Kirshenblatt - Gimblett, 1998).

Thus, in this research model, objects are thought either as heuristics devices for understanding the modes of everyday interaction and as empirical data for the construction of identity. Indeed, we can relate different stories with the same object, depending on the specific identity the owner wishes to invoke. The process of collecting

\footnotetext{
${ }_{1}^{1}$ The team involved in this project includes members with experience and interests in various academic fields (museology, design, design theory and history, interaction, philosophy and aesthetics), thereby ensuring the necessary skills for this project to succeed.
} 
and their visual narratives are therefore understood as heuristic devices; producing in-depth case studies on the development of collections and artefacts over time, ways of exhibiting, exploring, for example, motivations and nature of acquisition, new knowledge(s) and understanding of how narratives of the producer / collector / user are contained, constructed and reproduced in these materials and visual practices (i.e. modes exhibit). The very processes of materialization in this context are also a central theme of research. Moreover, we also aim at exploring the stories referring to objects in order to understand ways of knowledge (re) produced around these artefacts / collections and changes over time. A project of this nature necessarily uses a variety of methods, including interviews, which will lead us to the construction of biographies inspired by Lahire (2002) and based on personal biographical accounts, ethnographic observation and preparation of visual material. A methodological approach to the study of artefacts, collections is therefore deeply eclectic and eventually ethnographic, and while we will depart from materiality it is the social life of objects (Appadurai , 1986), their narratives (also visual ones) that are elected as its more interesting (and fundamental) locus for research that we aspire to develop.

In this sense, the project it will work as a "never ending story". We think we have the material and human resources to define, implement and evaluate the innovative methodologies and practices that can incubate a Centre to autonomously develop this research activity. For the moment, working around a small sample of representative artefacts is enough to validate our ideas from a scientific point of view.

Starting from a reference sample of Portuguese artefacts focused on examples of different types, chronologically scattered throughout the 2oth Century, emphasizing its poetic and innovative qualities, this project aims at the representation of these artifacts in the digital world, making them available to the comments of those who 'lived' with them. To achieve these objectives is necessary to:

(a) undertake epistemological research into the design, production and impact (social, economic and poetic) of these artefacts, in order to enable the construction of new expository narratives aimed at understanding "shape", both as a specific domain of this discipline, and as a physical translation of an idea; this will make use of a methodology that involves 'inverting' the design process (i.e. proceeding from the artefact to the idea); (b) create a taxonomic model/cataloguing system that provides all the information necessary for research and for the comprehension of the artefact from the point of view of the designer;

(c) produce digital representations of the artefacts on display;

(d) make those representations (and artefacts) technically available to the community for critical assessment, thus ensuring the vitality and durability of this museological and museographic initiative.

As a result CIDESP.PT expect to have published a book of monographs with the essential information about the studied

Portuguese artefacts (as Phaidon published about 1000 Design Classics) but also a website that enables a more profound design knowledge and interpretations about them. The monographs will establish a direct access and interaction with the virtual artefacts in the web platform, providing an augmented reality experience. The same strategies will be applied to the design of exhibitions with some of those physical artefacts enhanced with 
theme 2

memory

Figure 1.

(a) Raul Lino, publication of "Portuguese Houses", 1933 ,

(b) Manuelino Style

(c) 'Estado Novo' architecture, 1949 (d) Álvaro Siza Pavilion of Portugal at EXPO98 strand 3

design museums

the generated meta-information. We plan to develop this initiative with the collaboration of some Portuguese Museums related to the history of specific industrial or local activities. One of the first problems we were/are confronted is to establish distinctively Portuguese design criteria that could helps us to choose and analyze a sample of artefacts, without creating myths or clichés about the qualities of Portuguese identity, but rather to find cultural aspects that could drive future designing?

\section{Some thoughts on Portuguese Design}

The difficulty in finding half a dozen objects with which to build a museum of Portuguese design is due to a simple, yet complex issue - how to draw Portuguese design without being tempted by Raul Lino (fig1a). So that drawing would not close in on itself, but would instead be genuine, coherent and consistent, Álvaro Siza, using the same mediation of drawing, drew it so that it was open to cultural contamination of the other, reticently invoking the void of "poverty" as luxury and summoning the poetic through metaphor. These three conditions differentiate between Portuguese design based on the geography of the territory or on the nation's history: founded on cultural hybridisation (genotype) of a place which is a melting pot of many different cultures, concentrated here by the force of geographical circumstances, a cul-de-sac of European territory (for those whom follow the sun), Portugal also served as the point of departure and was thus connected with other distant, overseas cultures, both east and westward, the origin of emigration movements which have been taking place since the twelfth century. However, the lack of resources and consequent material poverty, has created conditions of isolation (phenotype) pragmatism and a scarcity of ornaments that promote artistic expression, if not indifferent, at least distrusting in their style (with rare exceptions, such as Manuelino
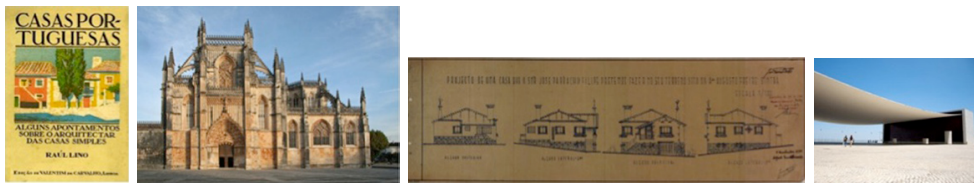

(fig.1b) and the 'Estado Novo' (fig.1c).

Throughout the history of Portuguese culture, there are frequent references to a poetic trend that begins with medieval Galician-Portuguese lyrics, which becomes more evident in the Renaissance with Camões and the modernist establishment of Fernando Pessoa. Poetry and "Fado" (Portuguese music) seem to constitute a mythical idealism, urgency in opening up to possibilities which is also characterized by the social exclusion which disregards reality.

Prado Coelho's acknowledgement of Portugal as a "country of poets" a sign of singular differentiation, is (alongside sarcasm), a figure of national style. Sarcasm, in the assumption of guilt, self-defeating and paradoxical, takes the impossible as a solution. So it seems that the pavilion of Portugal (fig. 1d), an expression of national identity, designed by Siza for Expo 98, links two antagonistic expressions of a country which is cultured, renaissancistic and neoclassical, to another, which is pragmatic and wild, a country which invents architecture without means, but rather according to desire.

These seem to be the three pillars of Portuguese design: cultural miscegenation, formal

2 This was remarked by both of the international consultants of our Project during a meeting with the team (Margolin, 2013: 1) (Dilnot, 2013: 6). 
laconism and the use of metaphor as argument. Unlike German design, that promises resistance and efficiency, or Italian design which promises elegance, Portuguese design of poetry, of creativity in existence.
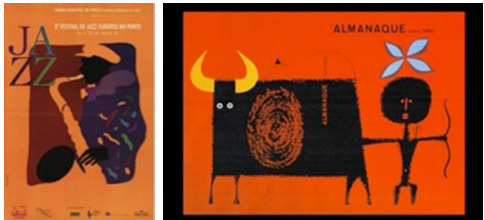

Authors such as João Machado (fig.2a) and Sebastião Rodrigues (fig.2b) may illustrate this idea, of using few resources, without abdicating the strong impact of metaphor in which each project will find the style of new arguments. Fernando Brízio (fig.za) is perhaps one of the most radical Portuguese designers, in terms of the imperative in poetry. However, Álvaro Siza's mirror table (fig.3b), the cutlery designed by Joaquim Ribeiro (fig.3c), or the filigree used by Liliana Guerreiro (fig.3d) also reflect exemplary 'portugality' in drawing.
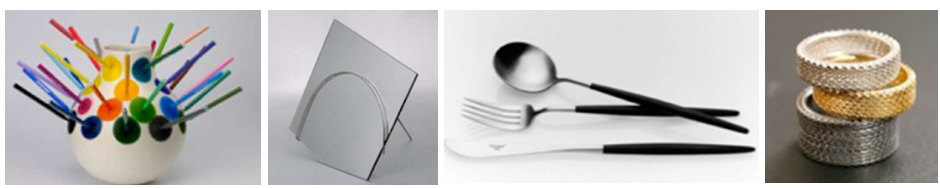

\section{Conclusion}

The project can have a very high impact either at a national level or internationally: Portugal, as other countries, don't have a museum devoted to the research and display of Portuguese Design and (as a consequence?) Portuguese industry typically "copies" or buys international design. So, this project is extremely relevant not only for the education of the new generations of designers, but also for the professional design activity and for the image of Portugal abroad. On the other hand, the project is based on an innovative methodological approach to this design research field that is open to the debate at an international level and can promote cultural encounters.

We hope to have rendered more visible three important dimensions:

- The high impact of this research project both at national and international levels, and its contribution to scientific knowledge and to the design profession and pedagogy;

- A new relation between physical archives (artefacts) and virtual models in order to enrich people experiences at exhibitions about design, based on new digital devices and on potential collaborations with some Portuguese Museums partially devoted to our material culture;

- An action-research and participatory methodology based on prototyping and on the dissemination of the results to evaluate the success of each step, either trough critical opinions of peers, or by the reactions of people we expect to visit and experiment this project initiatives.

\section{References}

APPADURAI, Arjun (1986) The social life of things: commodities in cultural perspective. In APPADURAI, Arjun (ed.). The Social Life of Things: Commodities in Cultural Perspective. Cambridge: Cambridge University Press. ISBN 978-0521357265
Figure 2.

(a) Poster by João

Machado, 1993:

(b) Magazine cover by Sebastião Rodrigues, 1960.

Figure 3 .

(a) Vase by Fernando Brízio, 2005; (b) Mirror by Álvaro Siza, 1975 (c) Cutlery by Joaquim Ribeiro 2006; (d) Filigree by Liliana Guerreiro, 2005. 
BARBOSA, Helena (2011) - "Uma história do design do cartaz português do século XVII ao século XX/One design history of the Portuguese poster from the 17th century to the 2oth century". Supervisor: Prof. Doutor Vasco Branco, Univ. of Aveiro, Co-supervisor: Anna Calvera i Sagué, Professor at University of Barcelona.

BARBOSA, Helena [et.al.] (2011) - "An innovative approach for design interpretation". In 9th International Conference European Academy - The Endless End. Porto: May, 2011. p. 86. http://endlessend.up.pt/site/?page_id=107

DILNOT, Clive (2013) Report: The Interpretation Center for Portuguese Design (CIDES.PT). DUDLEY, Sandra (2009) Museums materialities: objects, sense and feeling, in Sandra Dudley (ed.) Museum Materialities: Objects, Engagements, Interpretations. London, New York: Routledge, p. 1-18. ISBN 978-0415492188.

FRAGOSO, Margarida (2012) - Design gráfico em Portugal: formas e expressões da cultura visual do século XX. Lisboa: Livros Horizonte, 2012. 327 p. ISBN 978-972-24-1716-7. Giaccardi, E. (2006) - Collective storytelling and social creativity in the virtual museum: a case study. MIT Design Issues, Vol. 22, Number 3, Summer 2006.

HEIN, Hilde S (2000) The Museum in Transition. A Philosophical Perspective. Washington: Smithsonian Books. ISBN: 978-1560983965.

KIRSHENBLATT-GIMBLETT, Barbara (1998) Destination Culture: Tourism, Museums, Heritage, Berkeley e Los Angeles: University of California Press. ISBN 978-0520209664. LAHIRE, Bernard (2002) Portraits Sociologiques: Dispositions et Variations Individuelles, Paris : Nathan, Essais \& Recherches.

MANAÇAS, Vítor (2005) - Percursos do Design em Portugal. Lisboa: Faculdade de Belas Artes da Universidade de Lisboa, 2005. 2 vol. Tese de doutoramento em Design de Equipamento. Faculdade de Belas Artes da Universidade de Lisboa.

MARGOLIN, Victor (2013) Report of consultancy of the Project of Interpretation Center for Portuguese Design

SOUTO, Helena (2009) - História do design em Portugal I: reflexões. Lisboa: IADE edições, 2009. 94 p. ISBN 978-989-95639-2-6.

TABORSKY, Edwina (1990) The discursive object, in Objects of Knowledge, vol. 1, New Research in Museum Studies, London e Atlantic Highlands: Athlone Press, p.58-64. TILLEY, Chris; KEANE, Webb; KUCHLER; Susanne, ROWLANDS Mike; SPYER, Patricia (eds.) (2006) The Handbook of Material Culture. Londres, Thousand Oaks, New Delhi: Sage Publications, ISBN 978-1412900393.

VERGO, Peter (1989) The New Museology. Londres: Reaktion Books. ISBN 978-0948462030.

\section{Acknowledgements}

This work is funded by FEDER through the Operational Competitiveness Programme COMPETE - and by national funds through the Foundation for Science and Technology - FCT - in the scope of project PTDC/CPC-DES/4754/2012 (FCOMP-01-0124FEDER-028530).

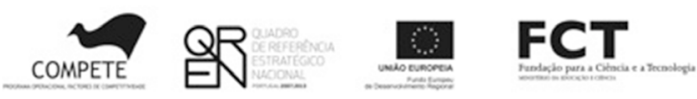

